\section{Determination of heavy metals and selenium content in chicken liver at Erbil city, Iraq}

\author{
Hoshyar Saadi Ali, ${ }^{1}$ Dhary Alewy \\ Almashhadany, ${ }^{1}$ Hawraz Sami Khalid ${ }^{2}$ \\ 'Department of Medical Lab Science, \\ College of Science, Knowledge \\ University, Kurdistan Region; \\ ${ }^{2}$ Department of Chemistry, College of \\ Education, Salahaddin University-Erbil, \\ Erbil, Kurdistan Region, Iraq
}

\begin{abstract}
Heavy metal contamination of poultry meat is a critical issue for human health due to associated risks of cytotoxicity and systemic pathologies after ingestion of such metals. A total of twenty chicken liver samples were collected from markets of Erbil city and analyzed for ten heavy metals contents by Inductively Coupled Plasma Optical Emission Spectrometry. The targeted metals were cadmium (Cd), cobalt (Co), chromium $(\mathrm{Cr})$, copper $(\mathrm{Cu})$, manganese $(\mathrm{Mn})$, nickel $(\mathrm{Ni})$, lead $(\mathrm{Pb})$, mercury $(\mathrm{Hg})$, zinc ( $\mathrm{Zn})$ and selenium $(\mathrm{Se})$. The average concentrations $(\mathrm{mg} / \mathrm{kg})$ of targeted trace elements were $0.06 \pm 0.027,0.06 \pm 0.05$, $2.05 \pm 0.34, \quad 1.85 \pm 0.47, \quad 0.15 \pm 0.17, \quad$ and $33.53 \pm 5.24$ for $\mathrm{Co}, \mathrm{Cr}, \mathrm{Cu}, \mathrm{Mn}, \mathrm{Ni}$, and $\mathrm{Zn}$ respectively. Copper $(\mathrm{Cu})$ levels significantly exceeded the maximum permissible limit of WHO. Moreover, the average concentrations of toxic heavy metals and selenium were $0.07 \pm 0.037,0.278 \pm 0.10$, $0.11 \pm 0.083$, and $2.01 \pm 0.454 \mathrm{mg} / \mathrm{kg}$ for $\mathrm{Cd}$, $\mathrm{Pb}, \mathrm{Hg}$, and $\mathrm{Se}$ respectively. $\mathrm{Hg}$ and $\mathrm{Pb}$ levels exceeded the permissible limits of WHO. Higher levels of $\mathrm{Cu}$ and $\mathrm{Hg}$ in poultry may pose a serious threat to consumers which demand countermeasures and precautions to be taken. Iraqi Standards Authority and relevant official institutions are strongly recommended to regulate safe disposal of heavy metal waste in the environment to reduce animal exposure to such metals.
\end{abstract}

\section{Introduction}

Poultry meat and edible offal are important components of human meat meals especially in eastern countries. Chicken meat and edible offal, specially livers, are two of the most commonly consumed poultry products in the Kurdistan Region (Iraq) in various preparations, including fast-food recipes. Liver is the vital organ responsible for metabolism and detoxification of numerous compounds such as therapeutic drugs, chemical toxic compounds, microbial toxins, and heavy metals (Almazroo et al., 2017; Bischoff et al., 2018). Heavy metals are metallic elements mainly found in earth's crust and characterized by high density (greater than $5 \mathrm{g.cm}^{-3}$ ) in comparison to water (Wang and Shi, 2001).

Certain heavy metals such as copper $(\mathrm{Cu})$, manganese $(\mathrm{Mn})$, nickel $(\mathrm{Ni})$, selenium (Se), chromium ( $\mathrm{Cr}$ ), and zinc ( $\mathrm{Zn}$ ), called micronutrients, are of paramount importance to all organisms in the three domains of life. They play important roles in enzymatic reactions, gene expression regulation (in folding of RNA, ribozymes catalysis, and ribosome functions), and energy metabolism (Draper et al., 2005; Denesyuk and Thirumalai, 2015; Kennelly, 2018). Despite the fact that the aforementioned heavy metals are required at low concentrations, higher concentrations may be toxic to cellular physiology (Kennelly, 2018). Still other heavy metals such as cadmium (Cd), arsenic $(\mathrm{As})$, and lead $(\mathrm{Pb})$ are highly toxic when ingested. They pose a serious threat to cardiovascular system, immune system, fetal cognition development, brain, lungs, kidney, liver, hematopoiesis, and normal cell cycle (Itoh et al., 2014; Jaishankar et al., 2014; Wu et al., 2016).

Industrial revolution and continuous development of agricultural fertilizers have contributed greatly to environmental pollution with high levels of heavy metals. Food chains are not excepted and received a fair share of heavy metal pollutants that accumulate in food chain living components, soil, vegetables, and water (Rai et al., 2019). Human is exposed to heavy metals via consumption of contaminated foodstuff, inhalation of polluted air, and dermal deposition from various sources. The continuous increase in heavy metals levels in food had led to wide investigations on heavy metals sources, bioaccumulation, and potential risks to human health (Mohmand et al., 2015; Rai et al., 2019). Published literature indicate a good correlation between heavy metals contents in animal feed and bioaccumulation level in various meats (Al Bratty et al., 2018; Kim and Koo, 2007; Wu et al., 2016). Frequent consumption of meat harboring high levels of heavy metals can result in accumulation of ingested metals in human tissues leading to toxicity and health hazards. Such implications of heavy metals in health hazards demanded World Health Organization (WHO), The European Food Safety Authority (EFSA), and many other regulatory authorities to set permissible
Correspondence: Dhary Alewy Almashhadany, Pathological Analysis Department, Knowledge University, College of Science, Erbil City, Kurdistan Region, Iraq.

Tel.: 009647733565479.

E-mail: dhary.hammed@knowledge.edu.krd

Key words: Accumulated metals, Kurdistan Region, selenium content, chicken liver, ICPOES

Contributions: The authors contributed equally.

Conflict of interest: The authors declare no conflict of interest.

Funding: This study was supported by Knowledge University and Salahaddin University-Erbil.

Patient consent for publication: Not applicable.

Received for publication: 4 November 2019. Accepted for publication: 19 March 2020.

This work is licensed under a Creative Commons Attribution-NonCommercial 4.0 International License (CC BY-NC 4.0).

(C) Copyright: the Author(s), 2020

Licensee PAGEPress, Italy

Italian Journal of Food Safety 2020; 9:8659

doi:10.4081/ijfs.2020.8659

limits for heavy metals in food.

Heavy metals contamination of different chicken tissues has been addressed in various published reports globally (Al Bratty et al., 2018; Bortey-Sam et al., 2015; Caldas et al., 2016; Hadyait et al., 2018; Khandia et al., 2015; Nazmul Haque et al., 2019). To the best of our knowledge, there is no previous study addressing the occurrence levels of heavy metals in chicken meat marketed in Erbil city. Therefore, the main objective of this study was to assess the level of some toxic heavy metals and selenium in different collected samples of chicken's liver available in markets of Erbil city.

\section{Materials and Methods}

\section{Samples and reagents}

All chemicals used in this study were purchased from Scharlau, Spain. The reagents were of analytical reagent grade quality including $50 \%(\mathrm{v} / \mathrm{v})$ hydrogen peroxide $\left(\mathrm{H}_{2} \mathrm{O}_{2}\right)$ and $65 \%(\mathrm{v} / \mathrm{v})$ nitric acid $\left(\mathrm{HNO}_{3}\right)$. Twenty frozen and fresh chicken liver samples were collected from popular local markets and chicken suppliers in Erbil city (Iraq) during Jun-July 2019. Samples characteristics are summarized in Table 1. Liver samples were cleaned with distilled 
water, labeled, and stored in polypropylene and preserved in the refrigerator until chemical analysis.

\section{Preparation and digestion of the samples}

Metal analysis was performed according to previously published method (Sadeghi et al., 2015). Briefly, liver sample was individually chopped, homogenized thoroughly using stainless steel knife and dried in an oven at $100^{\circ} \mathrm{C}$ for $12 \mathrm{~h}$ till constant weights were obtained. Dried samples were pulverized and homogenized by mortar. A weight of $0.70 \mathrm{~g}$ was placed into a digestion conical flask containing 5 $\mathrm{mL}$ of $\mathrm{HNO}_{3}(65 \%)$. The samples were left for acid digestion process using a classic digestion-heater at $150^{\circ} \mathrm{C}$ for 20 minutes. After cooling, $3 \mathrm{ml}$ of $\mathrm{H}_{2} \mathrm{O}_{2}(50 \%)$ were added to complete digestion process to each digestion flask. After completing digestion, each solution was cooled at room temperature and filtered into a flask and the volume was brought to $25 \mathrm{~mL}$ with deionized water. Finally, solutions were stored in appropriate plastic bottles for the investigation. The digestion procedures were individually repeated three times for each sample.

\section{Metal analysis}

Inductively Coupled Plasma Optical Emission Spectrometry (Spectro, Germany) was employed for the elemental analysis of digestion solutions. The contents of cadmium $(\mathrm{Cd})$, cobalt $(\mathrm{Co})$, chromium $(\mathrm{Cr})$, copper $(\mathrm{Cu})$, manganese $(\mathrm{Mn})$, nickel $(\mathrm{Ni})$, lead $(\mathrm{Pb})$, mercury $(\mathrm{Hg})$, zinc $(\mathrm{Zn})$ heavy metals and selenium ( $\mathrm{Se}$ ) were determined in all of the digested samples according to standardized procedures (Sadeghi et al., 2015; Deng et al., 2007). Finally, the estimated concentrations were measured in $\mu \mathrm{g} \cdot \mathrm{mL}^{-1}$ (parts per million) and then converted to $\mu \mathrm{g} \cdot \mathrm{g}^{-1}$ after using dilution factor (Sadeghi et al., 2015; Deng et al., 2007). Average concentrations were compared to permissible limits set by Codex Alimentarius Commission (FAO/WHO, 2011; CAC, 2019). Limits of detection was calculated according to the following equation;

$$
L O D=3 R S D b \frac{C}{S B R}
$$

where $\mathrm{RSDb}$ is the relative standard deviation of 10 replicates of the blank, $\mathrm{c}$ is the concentration of the standard, and SBR is the signal to background ratio. Limits of detection and wavelength for each element are in Table 2. All relevant ICP operating parameters were software controlled, allowing easy selection of the optimum operating conditions according to manufacture instructions (https://extranet. spectro.com/-/media/31793ADA-B987-4D 37-B597-04AFB66C7C22.pdf). The accuracy and precision of the method was investigated by analyzing the standard reference material SRM 1640 (Trace Elements in Natural Water). The measured value and the certified values were in excellent agreement for all elements.

\section{Statistical analysis}

All data were analyzed in version 21 of IBM SPSS package. One-sample t test was employed to test for heavy metal load difference between samples items and comparison of concentration means to the maximum permissible limits. One-way ANOVA analysis was performed to metaanalyze the difference of reported heavy metal levels in studies from Iraqi and other countries. Significance level was set to 0.05 .

\section{Results}

A total of twenty chicken liver samples were selected randomly and collected from supermarkets in Erbil city and local chicken supplies. Five liver samples were drawn from frozen chicken (CL 1-5) and the remaining samples were obtained from chicken slaughterhouses (CL 6-20). The details of collected samples and their origin are presented in Table 1. The average weight of liver samples was $68.7 \pm 36 \mathrm{~g}$.

\section{Total load of heavy metals}

The mean concentrations of detected heavy metals are depicted graphically in Figure 1. The average content of heavy

Table 1. Characteristics of collected chicken liver samples.

\begin{tabular}{|c|c|c|c|c|}
\hline Sample & Brand/type & Sample status & Sample origin (City) & Weight (g) \\
\hline 1 & Al Shemal & Frozen & Local (Erbil) & 60.1 \\
\hline 2 & Al Etimad & Frozen & Local (Erbil) & 62 \\
\hline 3 & Dorsa Morgh & Frozen & Imported (Iran) & 52.2 \\
\hline 4 & Dondurulmu Piliç Ci er & Frozen & Imported (Turkey) & 52.7 \\
\hline 5 & Time Food & Frozen & Imported (UAE) & 55 \\
\hline 6 & Broiler & Alive & Local (Erbil) & 57 \\
\hline 7 & Broiler & Alive & Local (Erbil) & 60 \\
\hline 8 & Broiler & Alive & Local (Erbil) & 67 \\
\hline 9 & Broiler & Alive & Local (Duhok) & 62 \\
\hline 10 & Broiler & Alive & Local (Duhok) & 70 \\
\hline 11 & Broiler & Alive & Local (Duhok) & 102 \\
\hline 12 & Golden Comet & Alive & Local (Erbil) & 34 \\
\hline 13 & Golden Comet & Alive & Local (Erbil) & 38 \\
\hline 14 & Golden Comet & Alive & Local (Erbil) & 40 \\
\hline 15 & Country Chicken & Alive & Local (Erbil) & 35 \\
\hline 16 & Country Chicken & Alive & Local (Erbil) & 39 \\
\hline 17 & Country Chicken & Alive & Local (Erbil) & 42 \\
\hline 18 & Parent Broiler & Alive & Local (Erbil) & 110 \\
\hline 19 & Parent Broiler & Alive & Local (Erbil) & 126 \\
\hline 20 & Parent Broiler & Alive & Local (Erbil) & 155 \\
\hline
\end{tabular}

UAE; United Arab Emirates. 
metals in chicken livers ranged from 1.98 to $8.98 \mathrm{mg} / \mathrm{kg}$ of dry weight. There is a significant difference between samples in terms of average heavy metal load $(p<0.001)$. Poor association has been found between liver weight and total heavy metal load $\left(\mathrm{r}^{2}=0.1795\right)$.

\section{Trace elements metals}

The details of trace elements metals detected in chicken liver samples are summarized in Table 3. Nickel was detected in only $40 \%(8 / 20)$ of samples, while chromium was found in $55 \%(11 / 20)$ of samples. Other trace element metals (Co, $\mathrm{Cu}, \mathrm{Mn}$, and $\mathrm{Zn}$ ) were detected in all samples. Of note, the means of $\mathrm{Co}, \mathrm{Cr}, \mathrm{Ni}$, and $\mathrm{Zn}$ did not exceed the permissible limit specified by WHO/FAO (Table 3). Indeed, the mean concentrations of these elements were significantly lower than maximum permissible limits of WHO. About $15 \%$ of samples exceeded the permissible limit of $\mathrm{Zn}$, while all samples significantly exceeded the permissible limit of $\mathrm{Cu}(\mathrm{p}<0.001)$.

\section{Toxic heavy metals, metalloids and}

\section{Selenium}

The mean concentrations of toxic heavy metals are summarized in Table 4. Mean concentration of cadmium $(\mathrm{Cd})$ in liver samples was significantly lower than permissible limit specified by WHO $\left(\mathrm{t}_{\mathrm{c}}=-\right.$ $27.745, \mathrm{p}<0.0001)$. Additionally, average of

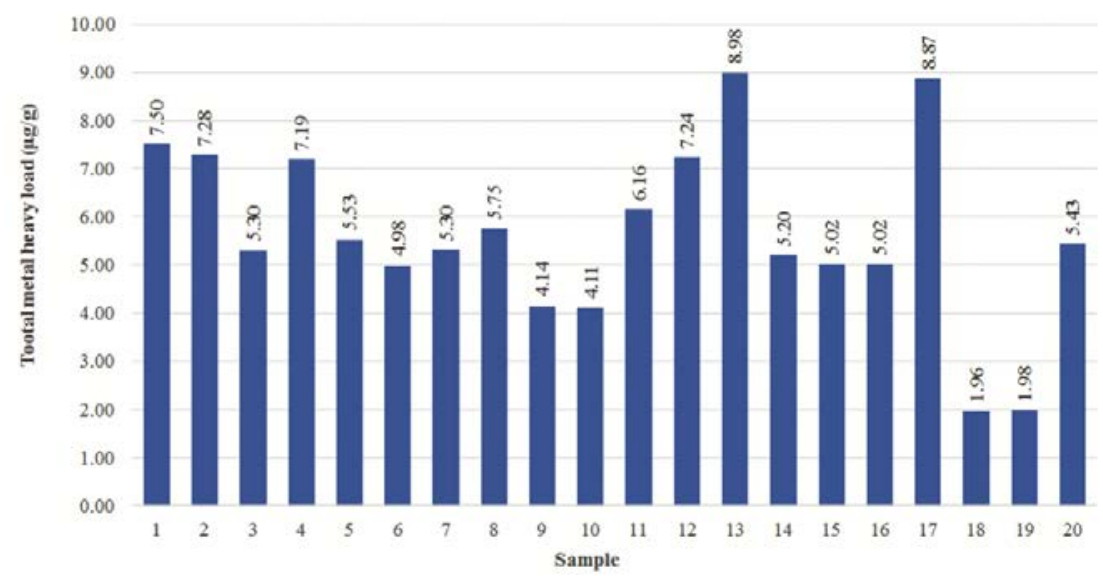

Figure 1. The means of total heavy metals concentration in chicken liver samples.

Table 2. Limits of detection (LOD) for the selected wavelengths (lines) for some elements.

\begin{tabular}{lcc} 
Element & Wavelength $(\mathrm{nm})$ & LOD \\
$\mathrm{Co}$ & 228.615 & 0.654 \\
$\mathrm{Cr}$ & 267.716 & 0.67 \\
$\mathrm{Cu}$ & 324.754 & 1.1 \\
$\mathrm{Mn}$ & 257.610 & 0.08 \\
\hline $\mathrm{Ni}$ & 231.604 & 0.95 \\
$\mathrm{Zn}$ & 213.856 & 0.2 \\
$\mathrm{Cd}$ & 214.438 & 0.333 \\
$\mathrm{~Pb}$ & 220.351 & 3.44 \\
$\mathrm{Hg}$ & 184.950 & 1.1 \\
$\mathrm{Se}$ & 196.090 & 6.8 \\
\hline
\end{tabular}

Table 3. Mean concentrations of trace elements metals in chicken liver samples expressed as in $\mathrm{mg} / \mathrm{kg}(\mathrm{mean} \pm \mathrm{SD})$.

\begin{tabular}{|c|c|c|c|c|c|c|}
\hline Sample & Co & $\mathrm{Cr}$ & $\mathrm{Cu}$ & Mn & $\mathrm{Ni}$ & $\mathrm{Zn}$ \\
\hline 1 & $0.074 \pm 0.011$ & 0.121 & $2.61 \pm 0.51$ & $2.14 \pm 0.23$ & ND & $45.07 \pm 18.55$ \\
\hline 2 & $0.044 \pm 0.034$ & 0.042 & $3.37 \pm 0.65$ & $2.03 \pm 0.45$ & 0.004 & $50.22 \pm 8.88$ \\
\hline 3 & $0.084 \pm 0.033$ & $0.101 \pm 0.035$ & $2.18 \pm 0.12$ & $1.94 \pm 0.16$ & ND & $30.69 \pm 7.58$ \\
\hline 4 & $0.035 \pm 0.014$ & 0.054 & $1.56 \pm 0.24$ & $1.47 \pm 0.82$ & 0.019 & $52.26 \pm 7.00$ \\
\hline 5 & $0.072 \pm 0.017$ & 0.051 & $2.51 \pm 0.40$ & $2.49 \pm 0.23$ & ND & $31.18 \pm 3.19$ \\
\hline 6 & $0.066 \pm 0.011$ & $0.035 \pm 0.033$ & $2.32 \pm 0.59$ & $2.30 \pm 0.47$ & ND & $28.29 \pm 6.44$ \\
\hline 7 & $0.061 \pm 0.024$ & 0.047 & $2.48 \pm 0.51$ & $2.16 \pm 0.86$ & 0.222 & $40.60 \pm 8.34$ \\
\hline 8 & $0.061 \pm 0.037$ & ND & $2.21 \pm 0.20$ & $2.95 \pm 0.56$ & ND & $26.35 \pm 3.86$ \\
\hline 9 & $0.069 \pm 0.022$ & $0.024 \pm 0.028$ & $1.97 \pm 0.15$ & $2.08 \pm 0.14$ & 0.328 & $22.38 \pm 3.07$ \\
\hline 10 & $0.047 \pm 0.015$ & ND & $1.50 \pm 0.37$ & $1.79 \pm 0.92$ & ND & $19.28 \pm 11.00$ \\
\hline 11 & $0.061 \pm 0.055$ & ND & $2.21 \pm 0.19$ & $2.16 \pm 0.27$ & 0.211 & $42.16 \pm 6.57$ \\
\hline 12 & $0.069 \pm 0.044$ & $0.032 \pm 0.053$ & $2.60 \pm 0.64$ & $2.24 \pm 0.45$ & 0.267 & $49.89 \pm 6.77$ \\
\hline 13 & $0.060 \pm 0.013$ & 0.128 & $2.40 \pm 0.59$ & $2.37 \pm 0.22$ & ND & $54.86 \pm 1.48$ \\
\hline 14 & $0.068 \pm 0.013$ & ND & $2.06 \pm 0.98$ & $2.29 \pm 0.82$ & ND & $24.10 \pm 11.06$ \\
\hline 15 & $0.083 \pm 0.011$ & ND & $1.16 \pm 0.13$ & $1.23 \pm 0.90$ & ND & $25.96 \pm 2.03$ \\
\hline 16 & $0.073 \pm 0.046$ & ND & $1.04 \pm 0.10$ & $1.18 \pm 0.60$ & ND & $26.10 \pm 2.90$ \\
\hline 17 & $0.039 \pm 0.019$ & ND & $1.86 \pm 0.23$ & $1.64 \pm 0.37$ & ND & $46.38 \pm 8.14$ \\
\hline 18 & $0.039 \pm 0.011$ & $0.073 \pm 0.015$ & $1.53 \pm 0.02$ & $0.968 \pm 0.075$ & 0.092 & $12.15 \pm 0.65$ \\
\hline 19 & $0.076 \pm 0.077$ & ND & $1.53 \pm 0.31$ & $0.807 \pm 0.172$ & ND & $8.60 \pm 2.68$ \\
\hline 20 & $0.034 \pm 0.028$ & ND & $1.95 \pm 0.19$ & $0.849 \pm 0.071$ & 0.039 & $34.03 \pm 3.84$ \\
\hline Mean & $0.06 \pm 0.027^{*}$ & $0.06 \pm 0.05^{*}$ & $2.05 \pm 0.34^{* *}$ & $1.85 \pm 0.47$ & $0.15 \pm 0.17^{*}$ & $33.53 \pm 5.24^{*}$ \\
\hline WHO PL & 1.0 & 1.0 & 0.4 & NS & 0.5 & 50 \\
\hline
\end{tabular}

*Significantly lower than maximum permissible limit $(\mathrm{p}<0.001),{ }^{* *}$ significantly higher than maximum permissible limit $(\mathrm{p}<0.001)$. PL: Permissible limit, ND: Not detected, NS: not specified yet. 
lead $(\mathrm{Pb})$ concentration significantly exceeded the permissible limit $\left(t_{c}=7.954\right.$, $\mathrm{p}<0.001)$. On the contrary, about $45 \%$ of samples exceeded the permissible limit set by WHO for mercury. The average of $\mathrm{Hg}$ in samples exceeded the limit was $0.11 \mathrm{mg} \cdot \mathrm{kg}^{-1}$ which was significantly higher than the limit $(\mathrm{p}=0.0281)$.

\section{Meta-analysis}

Locational variations between studies in terms of heavy metals in chicken liver samples were analyzed. Findings of previous studies from Iraq and other countries were analyzed with our findings. Meta-analysis showed no significant difference between locations of analyzed previous reports (Table 5 ) in terms of trace elements contents

Table 4. Concentrations of toxic heavy metals in chicken liver samples expressed as mean $\pm \mathrm{SD}\left(\mathrm{mg} \mathrm{Kg}^{-1}\right)$.

\begin{tabular}{|c|c|c|c|c|}
\hline Sample & Cd & $\mathrm{Pb}$ & $\mathrm{Hg}$ & Se \\
\hline 1 & ND & ND & $0.152 \pm 0.118$ & $2.35 \pm 0.24$ \\
\hline 2 & ND & ND & 0.286 & $2.21 \pm 0.58$ \\
\hline 3 & ND & ND & $0.099 \pm 0.091$ & $2.02 \pm 0.79$ \\
\hline 4 & $0.006 \pm 0.01$ & ND & $0.134 \pm 0.116$ & $1.97 \pm 0.45$ \\
\hline 5 & ND & 0.176 & ND & $2.23 \pm 0.50$ \\
\hline 6 & ND & ND & $0.083 \pm 0.082$ & $1.78 \pm 0.45$ \\
\hline 7 & ND & 0.329 & 0.138 & $1.70 \pm 0.90$ \\
\hline 8 & ND & ND & $0.103 \pm 0.042$ & $2.85 \pm 0.10$ \\
\hline 9 & ND & ND & ND & $2.14 \pm 0.41$ \\
\hline 10 & $0.034 \pm 0.059$ & ND & 0.007 & $2.03 \pm 1.01$ \\
\hline 11 & ND & 0.216 & $0.123 \pm 0.149$ & $2.10 \pm 0.57$ \\
\hline 12 & $0.115 \pm 0.078$ & 0.394 & ND & $2.41 \pm 0.70$ \\
\hline 13 & $0.150 \pm 0.088$ & ND & 0.075 & $2.95 \pm 0.15$ \\
\hline 14 & $0.079 \pm 0.015$ & ND & $0.043 \pm 0.02$ & $2.61 \pm 0.62$ \\
\hline 15 & $0.064 \pm 0.010$ & ND & $0.113 \pm 0.058$ & $1.56 \pm 0.12$ \\
\hline 16 & $0.054 \pm 0.027$ & ND & 0.170 & $1.56 \pm 0.22$ \\
\hline 17 & ND & ND & $0.048 \pm 0.013$ & $3.27 \pm 0.80$ \\
\hline 18 & $0.029 \pm 0.006$ & ND & $0.130 \pm 0.106$ & $0.708 \pm 0.082$ \\
\hline 19 & ND & ND & 0.080 & $0.763 \pm 0.282$ \\
\hline 20 & ND & ND & 0.100 & $0.975 \pm 0.357$ \\
\hline Mean \pm & $0.07 \pm 0.037^{*}$ & $0.278 \pm 0.100^{* *}$ & $0.11 \pm 0.083^{* *}$ & $2.01 \pm 0.454$ \\
\hline WHO PL & 0.3 & 0.10 & 0.1 & NS \\
\hline
\end{tabular}

*significantly lower than maximum permissible limit $(\mathrm{p}<0.001) .{ }^{* *}$ significantly higher than maximum permissible limit $(\mathrm{p}<0.001)$. PL: permissible limit. ND: not detected

$\left(\mathrm{p}=0.489, \mathrm{~F}_{\mathrm{c}}=0.84\right)$. The variations between locations in terms of toxic heavy metals and metalloids are summarized in Table 5. No ANOVA test was done for these metals due to lack of data, especially pertaining to $\mathrm{Hg}$ levels.

\section{Discussion}

Presence of heavy metals in meats is a public hazard due to the cytotoxicity of such metals and disruption of normal cellular processes. Poultry meat and edible offal are not excepted and are known to associate with risks to consumers including humans. This study evaluated the concentrations of heavy metals (trace elements and toxic metals and metalloids) in chicken liver samples collected from Erbil city, Kurdistan Region, Iraq.

The detected concentration of $\mathrm{Co}$ and $\mathrm{Cu}$ were $0.06 \pm 0.027 \mathrm{mg} / \mathrm{kg}$ and $2.05 \pm 0.344$ $\mathrm{mg} / \mathrm{kg}$ respectively. These concentrations are more than ten-fold higher than reported in previous study in Sulaimani city, Kurdistan $(0.006 \& 0.158 \mathrm{mg} / \mathrm{kg})$ (Aljaff et al., 2014). The mean of Co in this study (Table 3 ) was below the maximum permissible limit in poultry $(1.0 \mathrm{mg} / \mathrm{kg})$ set by Codex Alimentarius Commission (CAC, 2019; FAO/WHO, 2011). However, higher levels of $\mathrm{Cu}$ were reported from Pakistan (1.49 $\mathrm{mg} / \mathrm{kg}$ ) and $(1.60 \mathrm{mg} / \mathrm{kg}$ ) (Hadyait et al., 2018; Khan et al., 2015), Saudi Arabia (1.28 $\mathrm{mg} / \mathrm{kg}$ ) (Al Bratty et al., 2018), Bangladesh (4.37 mg/kg) (Mottalib et al., 2018), and Turkey (10.82 mg/kg) (Duman et al., 2019). These metals are essential micronutrients but are toxic at high level and can reach the foodstuff during food processing, agricultural activities, metals-contaminated

Table 5. Location variations between studies in terms of trace elements contents in chicken liver samples $\left(\mathrm{g} \mathrm{g}^{-1}\right)$.

\begin{tabular}{|c|c|c|c|c|c|c|}
\hline $\begin{array}{l}\text { Location (Reference) } \\
\text { Trace element }\end{array}$ & Co & $\mathrm{Cr}$ & $\mathrm{Cu}$ & Mn & $\mathrm{Ni}$ & $\mathrm{Zn}$ \\
\hline Erbil, Iraq (This study) & $0.06+0.03$ & $0.06 \pm 0.05$ & $2.05 \pm 0.34$ & $1.85 \pm 0.47$ & $0.15 \pm 0.17$ & $33.53 \pm 524$ \\
\hline Sulaimani, Iraq (Aljaff et al., 2014) & $0.006 \pm 0.0$ & $0.087 \pm 0.0$ & $0.16 \pm 0.0$ & $0.09 \pm 0.0$ & $0.09 \pm 0.0$ & $1.34 \pm 0.0$ \\
\hline Selangor, Malaysia (Abduljaleel et al., 2012) & $0.27 \pm 0.12$ & $5.13+0.69$ & $9.67 \pm 1.60$ & $7.11 \pm 1.77$ & $1.91 \pm 0.96$ & $78.86 \pm 21.45$ \\
\hline Benin, Nigeria (Ogbomida et al., 2018) & $0.05+0.03$ & $0.08 \pm 0.05$ & $4.36 \pm 1.02$ & $3.61 \pm 1.20$ & $0.02+0.01$ & $43.36 \pm 13.08$ \\
\hline Toxic metals & $\mathrm{Cd}$ & $\mathrm{Hg}$ & $\mathrm{Pb}$ & Se & & \\
\hline Erbil, Iraq (This study) & $0.07 \pm 0.04$ & $0.11+0.08$ & $0.28 \pm 0.10$ & $2.01+0.45$ & & \\
\hline Diyala, Iraq (Al-Zuhairi et al., 2015) & $0.095+0.0$ & NT & $0.095 \pm 0.0$ & NT & & \\
\hline Basrah Iraq (Hussein et al., 2012) & $0.04+0.03$ & NT & $1.29 \pm 1.09$ & NT & & \\
\hline Jazan, Saudi Arabia (AL Bratty et al., 2018) & $0.01+0.003$ & NT & $0.14+0.04$ & NT & & \\
\hline Mashhad, Iran (Sadeghi et al., 2015) & $0.37 \pm 0.09$ & NT & $3.79 \pm 3.64$ & NT & & \\
\hline Selangor, Malaysia (Abduljaleel et al., 2012) & $0.16 \pm 0.11$ & NT & $0.35+0.18$ & $2.01 \pm 0.60$ & & \\
\hline Benin, Nigeria (Ogbomida et al., 2018) & $0.29 \pm 0.34$ & $0.034+0.036$ & $0.17 \pm 0.19$ & NT & & \\
\hline
\end{tabular}

NT: not tested. 
chicken feed (Agade et al., 2019; Gall et al., 2015).

No permissible limit for Mn has been published by FAO/WHO or European Food Safety Agency. The average concentrations of $\mathrm{Zn}$ and $\mathrm{Mn}$ found in the present work are higher than previously published in Iraqi studies analyzed chicken meat samples including liver samples in Sulaimani and Diyala cities (Table 5) (Aljaff et al., 2014; Al-Zuhairi et al., 2015). However, the detected level of $\mathrm{Ni}$ in this study $(0.15$ $\mathrm{mg} / \mathrm{kg}$ ) was lower than the levels reported by the aforementioned Iraqi study in Diyala $(0.414 \mathrm{mg} / \mathrm{kg})$. No detectable level of Ni was also reported from Saudi Arabia (Al Bratty et al., 2018). Nonetheless, high concentrations of $\mathrm{Mn}$ in chicken liver samples were reported from Pakistan (6.26 $\mathrm{mg} / \mathrm{kg}$ ) (Khan et al., 2015), Turkey (9.45 $\mathrm{mg} / \mathrm{kg}$ ) (Duman et al., 2019) and as high as 119 mg/kg (Yayayürük \& Yayayürük, 2017). Lower levels of zinc were also reported from chicken liver samples analyzed in Saudi Arabia (20.72 mg/kg) (Al Bratty et al., 2018), Sulaimani city (Aljaff et al., 2014). On the contrary, higher concentrations were documented in Turkey (100.87 mg/kg) (Duman et al., 2019). The detected level of $\mathrm{Cr}$ found in this study $(0.06 \mathrm{mg} / \mathrm{kg})$ was lower than WHO maximum limit but significantly higher concentration was recently reported from Bangladesh (6.368 $\mathrm{mg} / \mathrm{kg}$ ) (Mottalib et al., 2018).

The average level of Cd observed in this study is lower than reported in previous studies conducted in Iraq $(0.095 \mathrm{mg} / \mathrm{kg}$ ) (AlZuhairi et al., 2015), Malaysia (0.159 $\mathrm{mg} / \mathrm{kg}$ ) (Abduljaleel et al., 2012), Nigeria $(0.29 \mathrm{mg} / \mathrm{kg})$ (Ogbomida et al., 2018), and Iran $(0.37 \mathrm{mg} / \mathrm{kg})$ (Sadeghi et al., 2015). One the other hand, higher contents that exceeded the permissible limit of FAO/WHO $(0.3$ $\mathrm{mg} / \mathrm{kg}$ ) have recently been reported from Bangladesh $(0.627 \mathrm{mg} / \mathrm{kg}$ ) (Mottalib et al., 2018). It's well-known that cadmium not only has no function in human body but also has a toxicity even at low levels due to its low excretion rate (Wu et al., 2016). Poultry can be exposed to Cd simply by contact with paints, electronic wastes, plastics, and cadmium-plated items and batteries (Rashid et al., 2013). Cadmium exposure is implicated in hepatotoxicity, respiratory diseases, and cancers of lung, kidney, and prostate (Rahimzadeh et al., 2017).

Exposure to organic mercury is linked to sever neurotoxicity in humans (Spiller, 2018). Detected concentrations of mercury exceeded the permissible limit set by $\mathrm{FAO} / \mathrm{WHO}$ was in $40 \%$ of samples. The mean concentration of $\mathrm{Hg}$ in the present work was $0.11 \pm 0.08 \mathrm{mg} / \mathrm{kg}$. This level is three-fold higher than reported in a recent study in Nigeria (Ogbomida et al., 2018). On the contrary, a higher level $(0.252 \mathrm{mg} / \mathrm{kg})$ was reported in chicken liver samples collected from markets in Izmir city in Turkey (Yayayürük \& Yayayürük, 2017). It should be noted that literature regarding $\mathrm{Hg}$ levels in poultry is scarce.

Lead in chicken liver samples was $(0.28$ $\mathrm{mg} / \mathrm{kg}$ ) two-fold higher than permissible limit of Codex Alimentarius Commission $(0.1 \mathrm{mg} / \mathrm{kg})$. This finding is even higher than reported by many reports from Saudi Arabia $(0.14 \mathrm{mg} / \mathrm{kg})$ (Al Bratty et al., 2018), and Nigeria $(0.171 \mathrm{mg} / \mathrm{kg})$ (Ogbomida et al., 2018). A worth mentioning point is that lead toxicity is mainly affecting hematopoiesis, kidney function, reproductive and central nervous systems (Assi et al., 2016).

Average selenium level found in this study is $2.01 \mathrm{mg} / \mathrm{kg}$ which is significantly greater than documented $(0.0174 \mathrm{mg} / \mathrm{kg})$ in previous study in Sulaimani city (Aljaff et al., 2014). However, a similar level of selenium was found in a Malaysian study (Abduljaleel et al., 2012). Till date, there is no permissible limit for selenium set by Codex Alimentarius Commission (WHO/FAO) or European commission. It was recently found that selenium assist mercury in its cellular toxicity by giving up its binding pockets in thioredoxin reductases and glutathione peroxidases enzymes to mercury. Mercury binding instead of selenium results in permanent inactivation of such enzymes (Spiller, 2018).

\section{Conclusions}

Trace elements metals of $\mathrm{Co}, \mathrm{Mn}, \mathrm{Ni}$, $\mathrm{Zn}$, and $\mathrm{Cr}$ in chicken liver samples collected from markets in Erbil city, Kurdistan (Iraq) did not exceeded the permissible limits of FAO/WHO. Likewise, average concentration of toxic heavy metals and metalloids did not exceed the maximum limits specified by WHO. However, $\mathrm{Cu}, \mathrm{Pb}$, and the heavy metalloid $\mathrm{Hg}$ exceeded the permissible limits in poultry set by WHO. These findings reflect the quality and safety of chicken meat sold in the markets. Iraqi Standards Authority is strongly advised to take precautions to lower the risks of poultry exposure to $\mathrm{Hg}$ and $\mathrm{Pb}$. Further investigations with larger sample size accompanied by risk assessment of heavy metal exposure in chicken is guaranteed to reveal a clearer picture of heavy metals in chicken meat in Erbil city.

\section{References}

Abduljaleel SA, Shuhaiml-Othman M, Babji
A, 2012. Assessment of trace metals contents in chicken (Gallus gallus domesticus) and quail (Coturnix coturnix japonica) tissues from Selangor (Malaysia). J Environ Sci Technol 5:441-51.

Agade YI, Faith EA, Muhammed M, 2019. Some heavy metals in different types and brands of poultry feeds in Lafia Metropolis. Int J Innov Food, Nutr Sustain Agric 7:1-5.

Al-Bratty M, Alhazmi HA, Ogdi SJ, Otaiif JA, Al-Rajab AJ, Alam MF, Javed SA, 2018. Determination of heavy metals in various tissues of locally reared (Baladi) chicken in Jazan region of Saudi Arabia: Assessment of potential health risks. Pak J Zool 50:1509-17.

Al-Zuhairi W, Farhan M, Ahemd M, 2015. Determine of heavy metals in the heart, kidney and meat of beef, mutton and chicken from Baquba and Howaydir market in Baquba, Diyala province, Iraq. Int J Recent Sci Res 6:5965-7.

Aljaff P, Rasheed B, Salh DM, 2014. Assessment of heavy metals in livers of cattle and chicken by spectroscopic method. J Appl Phys 6:23-6.

Almazroo OA, Miah MK, Venkataramanan R, 2017. Drug Metabolism in the Liver. Clin Liver Dis 21:1-20.

Assi MA, Hezmee MNM, Haron AW, Sabri MYM, Rajion MA, 2016. The detrimental effects of lead on human and animal health. Vet World 9:660-71.

Bischoff K, Mukai M, Ramaiah SK, 2018. Liver Toxicity. In: Gupta RC, ed, Veterinary Toxicology: Basic and Clinical Principles $3^{\text {rd }}$ Edition. Elsevier, Amsterdam, pp 239-57.

Bortey-Sam N, Nakayama SMM, Ikenaka Y, Akoto O, Baidoo E, Yohannes YB, Mizukawa H, Ishizuka M, 2015. Human health risks from metals and metalloid via consumption of food animals near gold mines in Tarkwa, Ghana: Estimation of the daily intakes and target hazard quotients (THQs). Ecotoxicol Environ Safety 111:160-7.

Caldas D, Pestana IA, Almeida MG, Henry FC, Salomão MSMB, de Souza CMM, 2016. Risk of ingesting $\mathrm{As}, \mathrm{Cd}$, and $\mathrm{Pb}$ in animal products in north Rio de Janeiro state, Brazil. Chemosphere 164:508-15.

Codex Alimentarius Commission (CAC), 2019. General standard for contaminants and toxins in food and feed. CXS 193 1995, Amendment 2019.

Denesyuk NA, Thirumalai D, 2015. How do metal ions direct ribozyme folding? Nat Chem 7:793-801.

Deng H, Zhang Z, Chang C, Wang Y, 2007. Trace metal concentration in great tit 
(Parus major) and greenfinch (Carduelis sinica) at the Western Mountains of Beijing, China. Environ Pollut 148:6206.

Draper DE, Grilley D, Soto AM, 2005. Ions and RNA folding. Annu Rev Biophys Biomol Struct 34:221-43.

Duman E, Özcan EM, Hamurcu MM, Özcan MM, 2019. Mineral and Heavy Metal Contents of Some Animal Livers. Eur J Sci Technol 15:302-7.

FAO/WHO, 2011. Joint FAO/WHO food standards programme Codex Committee on contaminants in foods fifth session working document for information and use in discussions related to contaminants and toxins in the GSCTFF (Prepared by Japan and the Netherlands). CF/5 INF/1.

Gall JE, Boyd RS, Rajakaruna N, 2015. Transfer of heavy metals through terrestrial food webs: a review. Environ Monit Assess 187:201

Hadyait M, Qayyum A, Bhatti E, Salim S, Ali A, Shahzadi M, 2018. Estimation of Heavy Metals in Liver, Gizzard, Breast and Thigh Muscles of Broiler Chicken in Different Area of Lahore by ICP-OES. PSM Vet Res 3:10-4.

Hussain RT, Ebraheem MK, Moker HM, 2012. Assessment of heavy metals (Cd, $\mathrm{Pb}$ and $\mathrm{Zn}$ ) contents in livers of chicken available in the local markets of Basrah city, Iraq. Basrah J Vet Res 11:43-51.

Hussein A, Khaled A, 2014. Determination of metals in tuna species and bivalves from Alexandria, Egypt. Egypt J Aquat Res 40:9-17.

Itoh H, Iwasaki M, Sawada N, Takachi R, Kasuga Y, Yokoyama S, Onuma H, Nishimura H, Kusama R, Yokoyama K, Tsugane S, 2014. Dietary cadmium intake and breast cancer risk in Japanese women: A case-control study. Int J Hyg Environ Health 217:70-77.

Jaishankar M, Tseten T, Anbalagan N, Mathew BB, Beeregowda KN, 2014. Toxicity, mechanism and health effects of some heavy metals. Interdiscip Toxicol 7:60-72.

Kennelly P, 2018. The biochemical roles of transition metals. In: Rodwell V, Kennelly P, Bender P, Weil P, Botham K, eds. Harper's Illustrated Biochemistry $31^{\text {st }}$ edn., McGraw-Hill, New York, pp 92-102.

Khan Z, Perween S, Gabol K, Khan IS, Baig N, Kanwal R, Jabeen T, 2015. Concentrations of heavy metals in liver, meat and blood of poultry chicken Gallus domesticus in three selected cities of Pakistan. Can J Pure Appl Sci 9:3313-24.

Khandia R, Munjal A, Bangrey RS, Mehra R, Dhama K, Sharma NC, 2015. Evaluation of silver nanoparticle mediated reduction of neovascularisation (angiogenesis) in chicken model. Adv Anim Vet Sci 3:3726.

Kim J, Koo TH, 2007. Heavy metal concentrations in diet and livers of Black-crowned Night Heron Nycticorax nycticorax and Grey Heron Ardea cinerea chicks from Pyeongtaek, Korea. Ecotoxicol 16:411-6.

Mohmand J, Eqani SAMAS, Fasola M, Almandar A, Mustafa I, Ali N, Liu L, Peng S, Shen H, 2015. Human exposure to toxic metals via contaminated dust: Bio-accumulation trends and their potential risk estimation. Chemosphere 132:142-51.

Mottalib MA, Zilani G, Suman TI, Ahmed T, Islam S, 2018. Assessment of trace metals in consumer chickens in Bangladesh. J Health and Pollut 8:1-10

Nazmul Haque M, Towhidul Islam MM, Tariqul Hassan M, Shekhar HU, 2019. Determination of Heavy Metal Contents in Frequently Consumed Fast Foods of Bangladesh. Proceedings of the National Academy of Sciences India Section B Biological Sciences 89:543-9.

Ogbomida ET, Nakayama SMM, BorteySam N, Oroszlany B, Tongo I, Enuneku
AA, Ozekeke O, Oshioriamhe M, Fasipe IR, Ezemonye LI, Mizukawa H, Ikenaka Y, Ishuzuka M, 2018. Accumulation patterns and risk assessment of metals and metalloid in muscle and offal of free-range chickens, cattle and goat in Benin City, Nigeria. Ecotoxicol Environ Safety 151:98-108.

Rahimzadeh MR, Rahimzadeh MR, Kazemi S, Moghadamnia AA, 2017. Cadmium toxicity and treatment: An update. Caspian J Intern Med 8:135-45.

Rai PK, Lee SS, Zhang M, Tsang YF, Kim KH, 2019. Heavy metals in food crops: Health risks, fate, mechanisms, and management. Environ Int 125:365-85.

Rashid K, Sinha K, Sil PC, 2013. An update on oxidative stress-mediated organ pathophysiology. Food Chem Toxicol 62:584-600.

Sadeghi A, Hashemi M, Jamali-Behnam F, Zohani A, Esmaily H, Dehghan AA, 2015. Determination of Chromium, Lead and Cadmium Levels in Edible Organs of Marketed Chickens in Mashhad, Iran. J Food Qual Hazards Control 2:134-8

Spiller HA, 2018. Rethinking mercury: the role of selenium in the pathophysiology of mercury toxicity. Clin Toxicol 56:313-26.

Wang S, Shi X, 2001. Molecular mechanisms of metal toxicity and carcinogenesis. Mol Cell Biochem 222:3-9.

Wu X, Cobbina SJ, Mao G, Xu H, Zhang Z, Yang L, 2016. A review of toxicity and mechanisms of individual and mixtures of heavy metals in the environment. Environ Sci Pollut Res 23:8244-59.

Yayayürük O, Yayayürük AE, 2017. Determination of Mercury, Lead, Cadmium, Copper, Iron and Manganese in Sheep, Cow and Chicken Liver Samples in Turkey. GIDA The J Food 42:546-52. 